\title{
Analysis of Impact of Exposures and Hydrological Modelling of Flood Peak Zones in Adamawa Catchment, Nigeria
}

\author{
Nwilo P. C. ${ }^{1}$, Olayinka N. D. ${ }^{1}$ and Adzandeh A. E. ${ }^{2, *}$ \\ ${ }^{1}$ Department of Surveying and Geoinformatics, University of Lagos, Akoka, Nigeria \\ ${ }^{2}$ African Regional Institute for Geospatial Information Science and Technology (AFRIGIST), Obafemi \\ Awolowo University, Ile-Ife, Nigeria \\ Corresponding Author: *ayilaj2013@gmail.com
}

https://doi.org/10.36263/nijest.2019.02.0148

\begin{abstract}
During the wet season, the Benue River overflows its banks and sometimes, extreme floods also occur in Adamawa catchment. Intensification of agriculture in some areas and urban growth in other areas has exposed a large population to flood risk. Little is known about localities or areas liable to flood at various peak flows and how land use and soil permeability affects the severity of flood in Adamawa catchment. This study seeks to analyse the exposures of land use/land cover and soil permeability to flood and model flood peak zones for three flow rates (2 years, 5 years and 10 years) using geospatial techniques and HEC-RAS model. Results of 2 years flood show that at least eight localities in the study area are highly prone to flood. This means that the probability of a flood of this calibre to occur and affect those localities in a given year is 50\%. The number of localities prone to flood increases for Annual Exceedance Probability of 20\% and 10\%. The probability of $10 \%$ flood to occur and affect those localities in a given year is relatively low compared to both the $2 y \mathrm{r}$ and $5 y \mathrm{r}$ flood. Modelling results generated a curve number grid map which shows the permeability levels within the study area. Areas with more infiltration capacity recorded 50\% (very high) and 20\% (high). Moderate permeability score $16 \%$. Very low and low levels account for $7.6 \%$ and $5.2 \%$ respectively. The implication is that $70 \%$ of the total area experience reduced surface runoff whereas $12.9 \%$ are more prone to water logging.
\end{abstract}

Keywords: Adamawa catchment, flood peak zones, Geospatial techniques, HEC-RAS model, land use/land cover, soil permeability to flood

\subsection{Introduction}

A number of notable researchers have defined floodplain. Floodplains are flat tract of land bordering a river, mainly in its lower reaches, subjected to recurrent flooding and consisting of alluvium deposited by the river (SURCON, 2004; Christopherson, 2012). Wolman and Leopold (1957) describe floodplains as relatively level and low relief landform periodically inundated by flow from adjacent river. Others opinion on what floodplain refers to are background oriented. The definition given for floodplains from several different perspectives, depending on goals in mind is documented by Schmudde (1968): "As a topographic category it is quite flat and lies adjacent to a stream; geomorphologically, it is a landform composed primarily of unconsolidated depositional material derived from sediments being transported by the related stream; hydrologically, it is best defined as a landform subject to periodic flooding by a parent stream. A combination of these characteristics perhaps comprises the essential criteria for defining the floodplain". Floodplain limits are defined by the peak water level of an appropriate return period event at the coast. Subhajit et al. (2010) explained that floodplains are formed by a complex interaction of fluvial processes. Christopherson (2012) reveal that, when river overflow its channel during times of high flow, floodplain is formed. Two types of floodplains are known. They are hydrologic and topographic floodplains. Hydrologic floodplains are floodplains along natural channels not affected by human activity (Schumm and Lichty, 1963; Burkham, 1972). Topographic floodplain is the area of land inundated by a flood of a specific magnitude and frequency, such as the 100-year flood (FISRWG, 1998). The topographic 
floodplain is of primary interest to engineers and floodplain managers concerned with flooding in developed areas (Coffman et al., 2000).

Floodplains are points of attraction for human activities because of its richness in nutrient for Fadama or wetland agriculture and availability of drinking water. They are species-rich environments often strongly impacted by human activities (Paillex et al. 2009; Tockner and Standford, 2002). According to Capon et al. (2009), ecologically, floodplains are areas of high productivity providing cover, shelter and food for biota in times of flooding and they hold high stores of plants and animals that can emerge during flooding. Floodplains constitute sinks for river-borne sediment and associated nutrients and contaminants; they are also sources of organic matter, nutrients and biota to the river during flooding (Capon et al., 2009). Contemporary floodplains are, in general, those lands most subject to recurring floods, situated adjacent to rivers and streams. They are therefore flood-prone and are hazardous to development activities if the vulnerability of those activities exceeds an acceptable level (OAS/DRDE, 1991). Floodplains exhibits dynamic pattern. OAS/DRDE (1991) observed that they are neither static nor stable. Fluvial processes (erosion and deposition) make a river to change its course and shift from one side of the floodplain to the other. The floodplain may be periodically modified by floods as the channel move back and forth across the floodplain. Strahler and Merali (2007) opined that when the floodplain is inundated, water spread from the main channel over floodplain deposits. As the current reduces, sand and silt are deposited in a zone next to the channel, creating natural levees-belt of higher land on either side of the river. Backswamp is a lower ground found between levees and bluffs that bound the floodplain. All these explain the characteristics of the dynamic pattern of floodplains.

The Benue River basin particularly Adamawa catchment is characterized by extensive fertile land which have led to intensification of agriculture in some areas and urban growth in other areas. For instance, in Adamawa, mid-sized cities like Jimeta and towns (such as Numan, Fufore, Demsa, Lamurde, Gombi and Ngurore in Adamawa State) situated along the Benue River floodplain are under the pressure of climate induced flood hazards. Seasonal floods in regions adjacent Major River like the Benue annually displaces thousands of people, many of them with no access to clean drinking water, leading to cholera outbreaks (Nwilo et al., 2012). The main concern is that little is known about localities or areas liable to flood at various peak flows. Also, there is dearth of information regarding how land use and land cover (LULC) and how soil permeability affects the severity of flood in Adamawa catchment. The purpose of this study is to analyse the exposures of land use/land cover and soil permeability to flood and delineation areas liable to flood for three flow rates ( 2 years, 5 years and 10 years) using geospatial techniques, HEC-GeoRAS and HEC-RAS model.

\subsection{Methodology}

\subsection{Description of the study area}

The study area is Adamawa catchment. The site is along river Benue in the Upper Benue drainage basin of Nigeria. It cuts across the boundaries of six local governments' areas in Adamawa State Demsa, Funfore, Ngurore, Numan, Yola North, and Yola South. The major towns in the investigated area are Numan, Jimeta and Yola. The location occupies large floodplain zone in Nigeria. NFDP-II (2003) observed that about 30\% of the lowlands in Nigeria are situated in the central part (Kogi, FCT, Nasarawa and Benue States) and about 55\% in the eastern area (Plateau, Taraba and Adamawa States). The floodplain ecosystems are subjected to seasonal flooding and are naturally rich in nutrients deposited in the plains as the floodwaters recede. Large volumes of sediment are seasonally discharged into the floodplains and help to renew the fertility of the soils. The climate and weather of the study area are controlled largely by its location along the Benue trough, its position at the north of the Equator and the prevailing winds which follow the movement of thermal Equator. Adamawa has a tropical climate characterized by dry and wet seasons. Dry season lasts for a minimum of five months (November-March) while the wet season spans April to October. Temperature in the region can be as high as $40^{\circ} \mathrm{C}$ and as low as $18^{\circ} \mathrm{C}$. The relief is nearly level to gentle undulating plain with few outcrops. The Sub-catchment border is approximately defined by longitudes $11^{\circ} 46^{\prime} \mathrm{E}$ and $14^{\circ} 14^{\prime} \mathrm{E}$ and latitudes $8^{\circ} 37^{\prime} \mathrm{N}$ and $9^{\circ} 41^{\prime} \mathrm{N}$ (Figure 1). The land area is about $6,685 \mathrm{~km}^{2}$. 


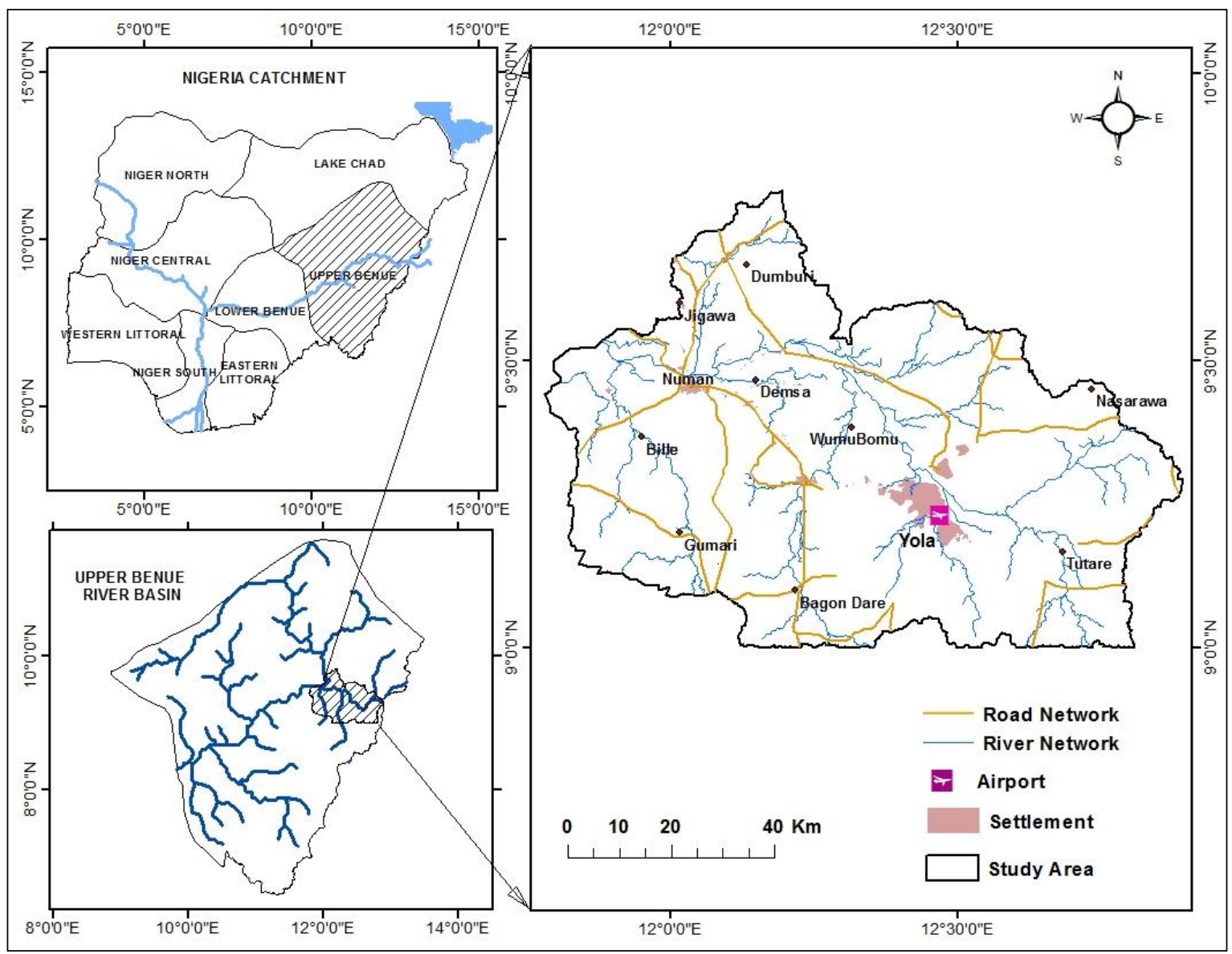

Figure 1: Reference map of the study area

\subsection{Data collection}

Secondary data were sourced and used in this study. They include; Digital Elevation Model (DEM) sourced from Advanced Spaceborne Thermal Emission and Reflection Radiometer (ASTER) Global DEM with a resolution of $30 \mathrm{~m}$, Landsat Operational Land Imager-Thermal Infrared Sensor (OLITIRS) image for 2018 with a resolution of $30 \mathrm{~m}$ downloaded from the United States Geological Survey (USGS) website, soil map from the 1996 compilation of soil map for Nigeria: a nationwide soil resource and land form inventory by Centre for World Food Studies (SOW-VU) with a resolution of 1: 1:300,000, and Precipitation. Based on the availability of data, predicted precipitation data is used in this study. It was obtained from the downscaled IPPC5 (CMIP5) data using Global Climate Model (GCM) CCSM4 under scenario representative concentration pathway (RCP) 6. There are two periods of time with available predicted precipitation in CMIP5 dataset. They are that of 2014 to 2060 and 2061 to 2080 . That for 2014 to 2060 was chosen since it is the available data for the nearest future.

\subsection{Description of procedure}

\subsubsection{Processing of land use/land cover, soil and precipitation datasets}

Datasets acquired were processed at this stage to generate map layers. Land use and land cover (LULC) map of the investigated area was derived using the $30 \mathrm{~m}$ resolution Landsat OLI-TIRS of 2018. The topographic sheets with a scale of 1:50,000 and land cover shapefile from National Space Research and Development Agency (NARSDA) and Google Earth image were used to generate base layers of the catchment boundary, etc. Supervised image classification using maximum likelihood algorithm was applied in ENVI software environment because of its popularity and wide acceptance. Duda et al. (2000) and Akintunde et al. (2016) opined that the maximum likelihood algorithm classification method is one of the superior methods of classification, because it uses various classification decisions using probability and cost functions in categorizing pixels into its corresponding class. The LandSat image was classified into fourteen feature classes based on Africover land cover classification system (FAO, 2005; FAO, 1997) namely; alluvial, grassland, forest, gullies, settlement irrigation project, floodplain, shrub/freshwater marsh, water bodies, riparian forest, 
rainfed agriculture, reservoir, arable crop plantation and tree crop plantation. Error matrix was performed for classification accuracy assessment, and the overall accuracy and Kappa coefficient were determined. Predicted precipitation data was used in this study to generate precipitation distribution map for the catchment in ArcGIS software. This was also used in the work of Xinyi (2016) to produce similar map. Soil layer characteristics of the study area were derived from the soil map of Nigeria through on-screen digitizing in ArcGIS environment. The LULC, soil and precipitation layers/maps produced were further used as input for floodplain analysis.

\subsubsection{Floodplain analysis}

Floodplain analysis conducted here concentrates on two aspects. The first aspect is to analyze the impact of exposures on the floodplain. The task entails developing hydrologic model for the study basin in HEC-HMS and hydraulic modelling (HEC-RAS modelling) (US-ACE, 2011) to predict the movement of the runoff water over the surface. The second aspect focused on flood inundation mapping at various flow rates.

\subsubsection{Analysis of impact of exposures:}

Impact of exposures in this study focuses on land use pattern and soil drainage characteristics (permeability). Information from exposures of land use and soil permeability to flood gives insight in the interpretation of how land use and soil permeability affects the severity of flood in the investigated area. HEC-GeoHMS preprocessing of the LULC was carried out in ArcGIS environment. HECGeoHMS was used to define some distributed hydrological parameters and inputs for the project area. To define excess rainfall water volume, the SCS method was selected. This method, according to USSCS (1986) uses the Curve Number (CN) Grid- a hydrological parameter- to calculate hydrological properties for the whole basin. The $\mathrm{CN}$ is the most important parameter for the hydrological model, because of the methods used to accomplish it (US-SCS, 1986). For the creation of the CN grid, the composite land use/land cover polygon shapefile created together with soil type information were used. For the $\mathrm{CN}$ method, all the types of soil were classified into four categories. In the composite land use attribute table, some fields were added to create CNLookup table with the Curve Number corresponding to the land cover for each class of soil (A- D). The CN Grid was finally created by defining the hydrologically corrected DEM, the composite LULC and the CNLook up table in ArcGIS.

\subsubsection{Maping of flood peak zones:}

Going further, a hydraulic model (HEC-RAS modelling) was used to predict the movement of the runoff water over a surface. HEC HMS hydrological model was used to create rainfall-runoff volume which serves as input for the HEC-RAS modelling and the model analyses the way the water moves on the project area and the places where it concentrates creating inundation problems. HEC-RAS is designed to perform 1-dimensional and 2-dimensional hydraulic calculations for a full network of natural and constructed channel, overbank/floodplain areas, and so on. The geometrical data needed for the hydraulic model that would be developed in HECRAS, was extracted from the terrain model (DEM) by use of the HEC-GeoRAS extension. The work flow is explained under the following sub heading.

(a) HEC-GeoRAS preprocessing: HEC-GeoRAS is a set of ArcGIS tools specifically designed to process geospatial data for use with the HEC-RAS. It is an extension that allows one to create an HEC-RAS import file containing geometric data from an existing digital terrain model (DTM) and complimentary data sets. The processes involved are: (1) Definition of geometrical data extraction operations (2) Stream centreline (3) Bank lines (4) Flowpath centrelines (5) XS (Cross-sectional) cutlines (6) Assigning Manning's n values (7) Layer setup. The geometric data was then imported into HEC-RAS.

(b) Steady flow data: The next step in the hydraulic model development was adding steady flow data. The assumption that we deal with a steady flow situation was made. The function of steady flow analysis is to apply a time series of discharge rates at each river reach in the computation of cross sectional hydraulic flow. The discharge rates were fed into columns termed as profiles in the steady flow data workspace. The profiles would read information from the HMS discharge model results at specified time steps. To do this, a DSS (data store) connection was made to the location of the data store of results from the HMS model run. Next was to return to the Steady Flow Data page to load 
HMS discharges for the reaches at the specified time window. Reach boundary conditions was defined using the Reach Boundary Conditions button which opens a new tab. There, the boundary for each downstream reach, where there was no junction, was defined. The Normal Depth button was selected and 0.0004 served as input. Finally, the datasets were ready and the model was ready to be run. The result of the described steps was the population of discharge profiles for each element in the geometric model. The profiles were assigned to individual columns for each time step in the HMS model run. The profile names were edited to the time interval needed for floodplain delineation. To run the Steady flow analysis, a computation plan was created. The subcritical flow method was chosen. Flow distribution locations were specified in order for flow velocity to be computed. The Flow distribution location window defined the number of subsections for Channel, Left Overbank and Right Overbank breaks that are required in flow energy levels computation. Other options that were applied were Encroachment and Conveyance Calculations. For the latter, the break points or change stations of Manning's $n$ coefficients were used in the analysis.

The steady flow computation determines water surface levels of the flood inundation. Several interfaces exist in the HEC-RAS application for visualizing water levels as they change over time. These were viewed for each cross section, stream reaches and also as X-Y-Z Perspective profile plots. To visualise the results, they were exported to a GIS format so it can be opened in a GIS environment.

(c) Post-processing and flood mapping: The post-processing and mapping of the model results were performed in ArcGIS using the HEC-GeoRAS extension. The steps are as follows: (1) Convert to XML format, (2) Layer setup, (3) Water surface TIN generation, and (4) Floodplain delineation: This used the water surface TIN generated and the terrain model to calculate the floodplain boundary and inundation depths.

\subsection{Results and Discussion}

\subsection{Land use/land cover, soil and precipitation mapping}

Map layers such as land use/land cover (LULC), soil and precipitation were created in this study. Predicted precipitation data was used to generate precipitation distribution map for the catchment. The map (Figure 2) indicates that, rainfall throughout the year ranges from $237 \mathrm{~mm}$ to $271 \mathrm{~mm}$. Adamawa in general is naturally divided into two ecological zones; the guinea and Sudan savannah zones. Majority of the population living in the area depends on agriculture as means of livelihood.

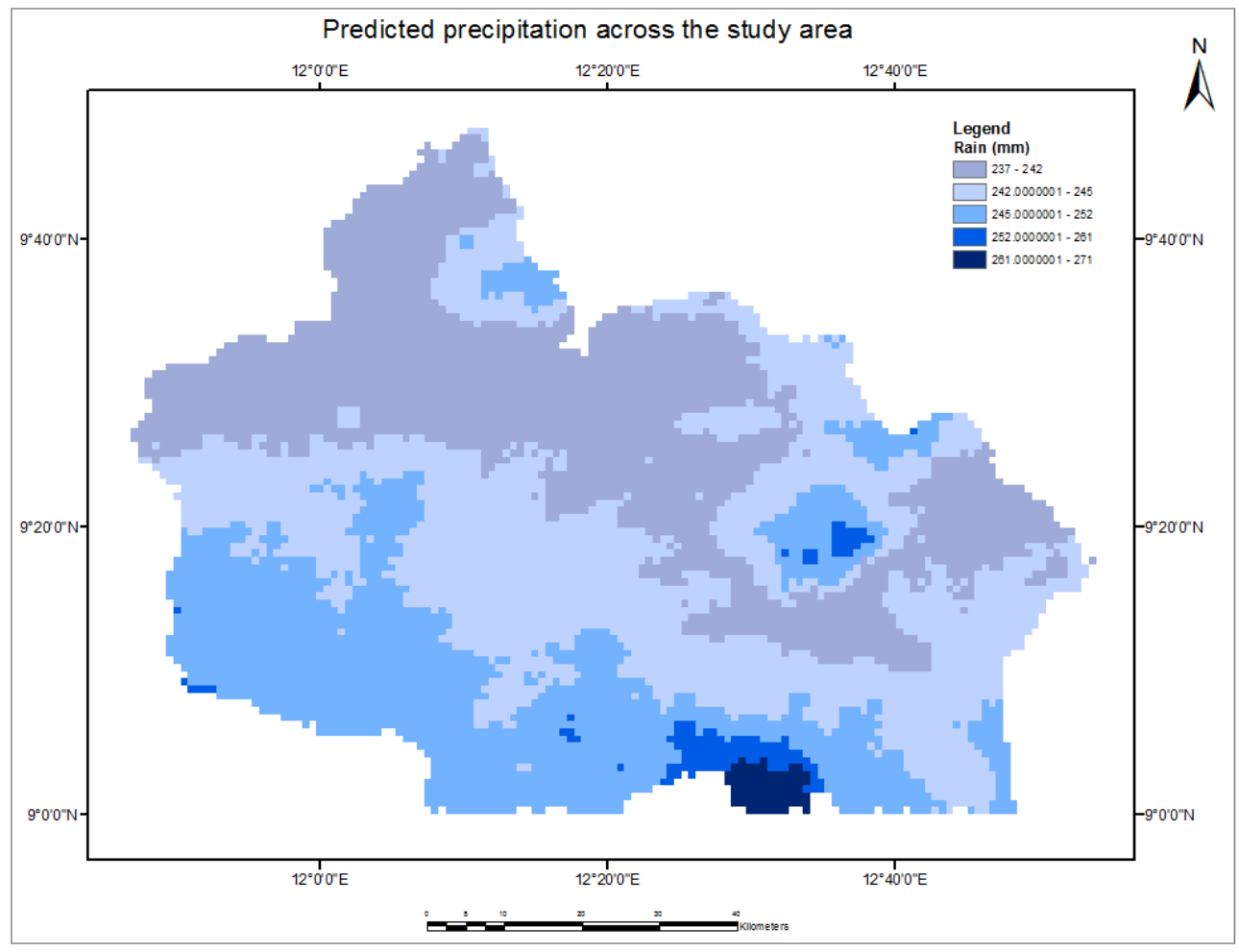

Figure 2: Reference map of precipitation 
Agriculture is the mainstay of about $80 \%$ of the inhabitants of the area (Adebayo, 1997). Irrigation projects along the Benue and its tributaries in the study area have provided a year round agricultural practice. Also, the ecological condition of the area permits cultivation of root crops, cereals and rearing of livestock in large numbers.

Results of soil mapping shows that there are different types of soils within the study areas (Figure 3) but loamy sandy soils were predominant. Other soils observed in the area are: clay loamy, sandy clay, and sandy loam. Soil has impact on flooding. Nicholls and Wong (1990) observed that the soil types in an area is important as they control the amount of water that can infiltrate into the ground, and hence the amount of water which becomes flow. When the amount of flow is high such that the capacity of the soils could not contain, flood occur. The chance of flood hazard increases with decrease in soil infiltration capacity, which causes increase in surface runoff. When water is supplied at a rate that exceeds the soil's infiltration capacity, it moves down slope as runoff on sloping land, and can lead to flooding (Lowery et al., 1996).

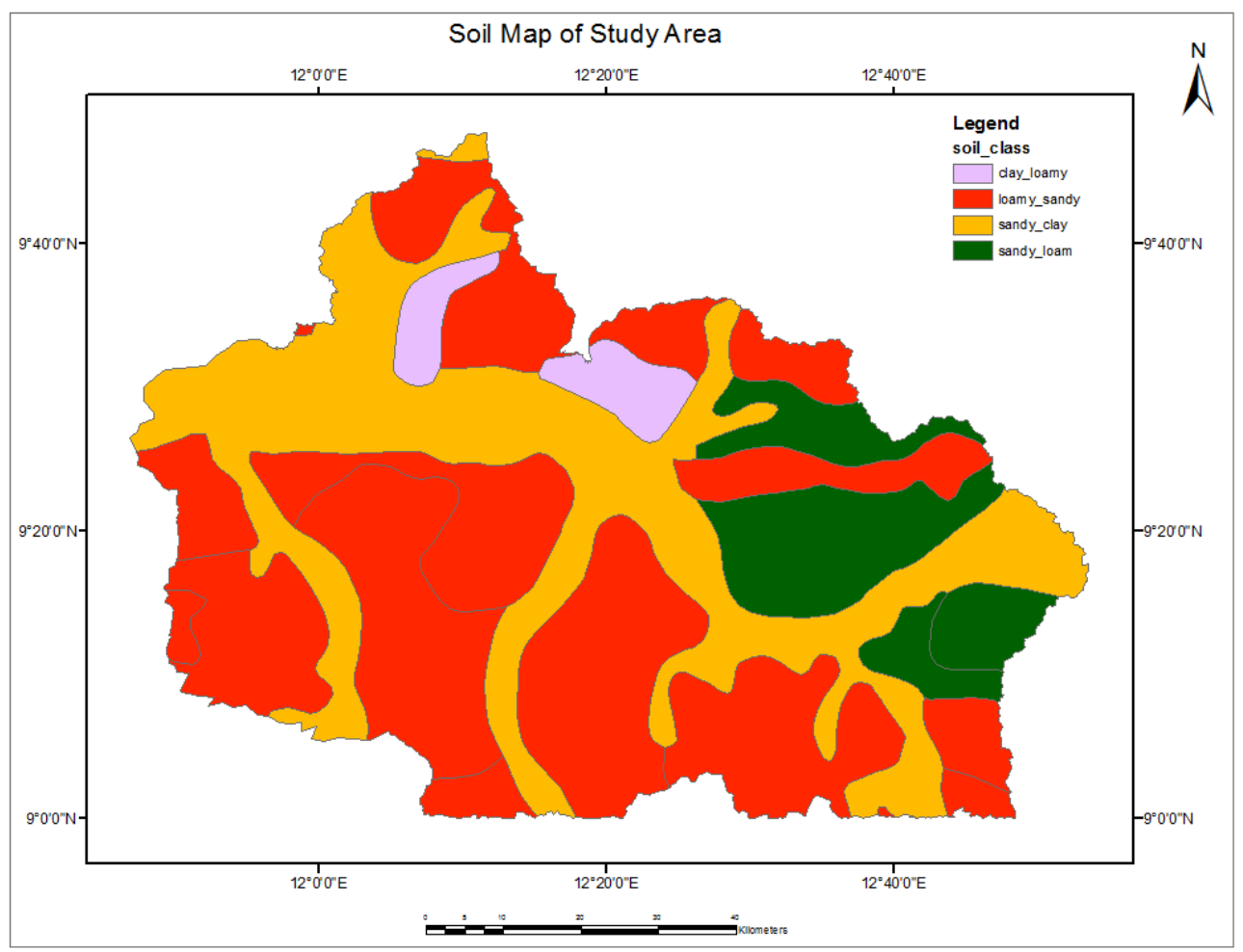

Figure 3: Soil map of the study area

Land use/ land cover analysis was conducted using Landsat 8 image of 2018. The LandSat image was classified into fourteen feature classes namely; alluvial, grassland, forest, gullies, settlement irrigation project, floodplain, shrub/freshwater marsh, water bodies, riparian forest, rainfed agriculture reservoir, arable crop plantation and tree crop plantation. Error matrix was performed to determine the classification accuracy, and the overall accuracy of $98 \%$ and Kappa coefficient of 0,994 were obtained. The LULC map produced is shown in Figure 4. The analysis reveals that rainfed agriculture occupies the highest area $(53 \%)$. Tree crop plantation was seen to have least coverage $(0.06 \%)$. Settlement and floodplain agriculture occupy $1.67 \%$ and $10.2 \%$ of the area respectively. Table 1 captures details of the LULC distribution in the case study area. 


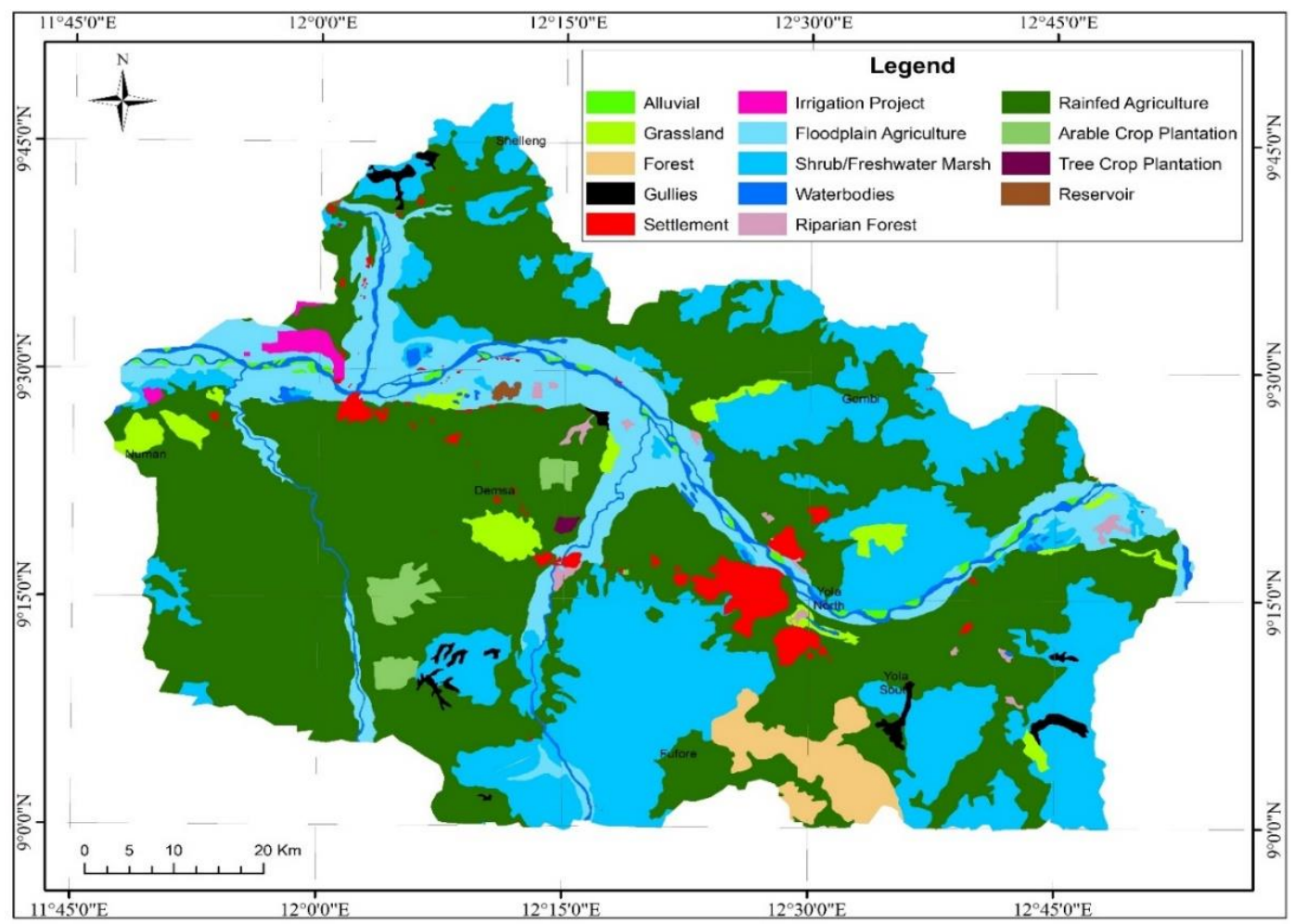

Figure 4: LULC map

Table 1: Distribution of land use and land cover

\begin{tabular}{|l|l|l|}
\hline \multirow{2}{*}{ Land Use/ Land Cover } & Area \\
\cline { 2 - 3 } & $\mathrm{km}^{2}$ & $\%$ \\
\hline Alluvial & 25.41 & 0.38 \\
\hline Grassland & 135.27 & 2.02 \\
\hline Forest & 148.12 & 2.22 \\
\hline Gullies & 9.41 & 0.14 \\
\hline Settlement & 111.62 & 1.67 \\
\hline Irrigation Project & 28.61 & 0.43 \\
\hline Floodplain Agriculture & 687.64 & 10.29 \\
\hline Shrub/Freshwater Marsh & 1723.71 & 25.79 \\
\hline Water bodies & 139.93 & 2.09 \\
\hline Riparian Forest & 27.70 & 0.41 \\
\hline Rainfed Agriculture & 3573.03 & 53.45 \\
\hline Arable Crop Plantation & 64.32 & 0.96 \\
\hline Tree Crop Plantation & 4.28 & 0.06 \\
\hline Reservoir & 5.68 & 0.09 \\
\hline Total & 6684.74 & 100.00 \\
\hline $\begin{array}{l}\text { Overall accuracy }=98.866 \\
\text { Kappa coefficient }=0.994 .\end{array}$ & \\
\hline
\end{tabular}

\subsection{Impact of exposure}

Impact of exposures was investigated in the study area. The outcome (maps) of LULC alongside soil information was used as parameters for generating a permeability map. Exposures of land use/land cover and soil permeability to flood denote how land use and soil permeability affects the severity of flood. Urban land use pattern results in an impervious soil layer increasing the severity of flood and thus, the exposure of land use pattern to flood in an urban area is high. Exposure of soil permeability to flood have direct link to flood flow. Soil permeability refers to the hydrological drainage characteristic of soil to allow water movement through its pores, which is inversely proportional to soil density (Subhankar et al., 2010). The more permeable soil has more infiltration capacity and therefore, reduces surface runoff, whereas less permeable soil has less infiltration capacity and is more prone to water logging (Grosshans et al., 2005). The Curve number $(\mathrm{CN})$ grid map which show the permeability level within the study area (Figure 5) and a background basin map (Figure 6) were generated as thoroughly explained in the methodology. The $\mathrm{CN}$ relies mainly on soil data and LULC data. The breakdown of the permeability level within the study area is as shown in Table 2. About 
$50 \%$ of the investigated area is seen with very high permeability level. Only a total of $293.64 \mathrm{~km}^{2}$ $(5.2 \%)$ of the area have low level. Moderate and high permeability levels score $16 \%$ and $20 \%$ respectively. About $7.6 \%$ recorded very low level.

Table 2: Breakdown of permeability level

\begin{tabular}{|l|l|l|}
\hline \multirow{2}{*}{ Permeability level } & Area \\
\cline { 2 - 3 } & $\mathrm{km}^{2}$ & $\%$ \\
\hline Very low & 432.11 & 7.69 \\
\hline Low & 293.64 & 5.23 \\
\hline Moderate & 906.51 & 16.13 \\
\hline High & 1134.73 & 20.20 \\
\hline Very high & 2851.63 & 50.75 \\
\hline Total & 5618.62 & 100.00 \\
\hline
\end{tabular}

The more permeable the soil is, the more water can be transmitted through it. A soil with low permeability, such as clay, doesn't permit much water flow. This could cause "pudding" of water and thus higher accumulation of water on the soil surface. Regions which are composed primarily of these types of soils are prone to a higher flood risk because the water requires a longer time to drain or infiltrate into the ground (Grosshans et al., 2005).

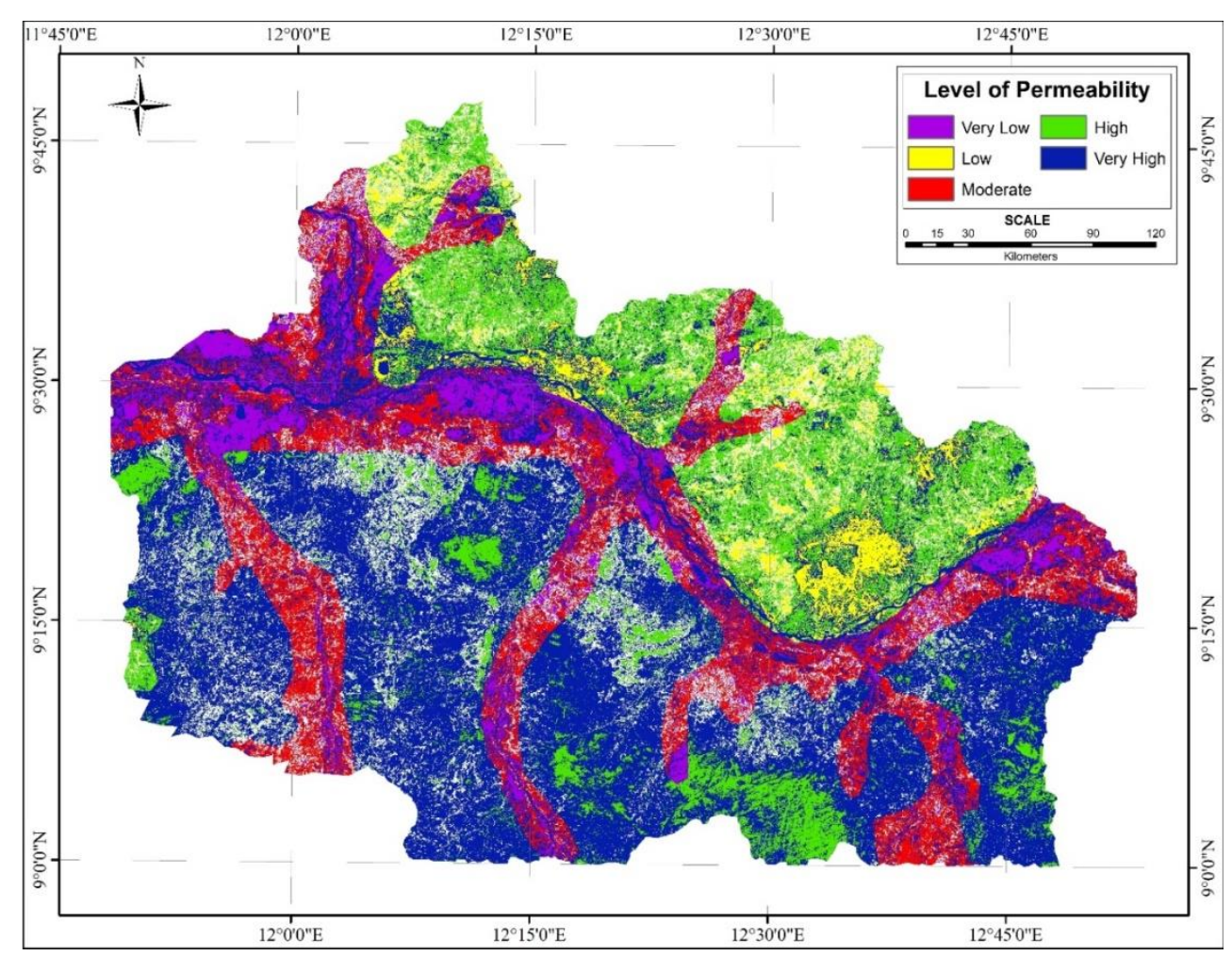

Figure 5: CN grid map

\subsection{Hydrological modelling of peak flows}

Hydrological modelling of peak flows was carried out using HECRAS. The purpose is to have insight about localities or areas liable to flood at various peak flows for River Benue which is the major river in the study area. Three flow rates were specifically analyzed ( 2 years, 5 years and 10 years) based on availability of flow data, and the resulting floodplains were mapped using HEC-GeoRAS on ArcMap. The delineation and analysis of the floodplain and areas liable to flood for peak flows of the 2 years flood, or Annual Exceedance Probability (AEP) of 50\%, revealed that Eight (8) localities in the study area are highly prone to flood (Figure 6). They include: Rumude, Njaredi, Kabawa Changala, Rugange, Sabon Gari Rugange, Yola, Rumude Mallum Yolde Pate, and Modire Yolde Pate (Figure 6). This means that the probability of a flood of this calibre to occur and affect those localities in a given year is $50 \%$ or 0.5 . The chances of this flood occurring is very high. Results of the 5 years flood, or AEP of $20 \%$, recorded a total of ten (10) areas as highly prone to flood (Figure 7). Two more localities in addition to the eight mentioned earlier are now included. The two additional localities are Nambare and Dumdere. Since, the probability of a flood of this calibre to occur and affect those 
localities in a given year is $20 \%$ or 0.2 , the chances of this flood occurring is relatively low compared to the 2 years flood.

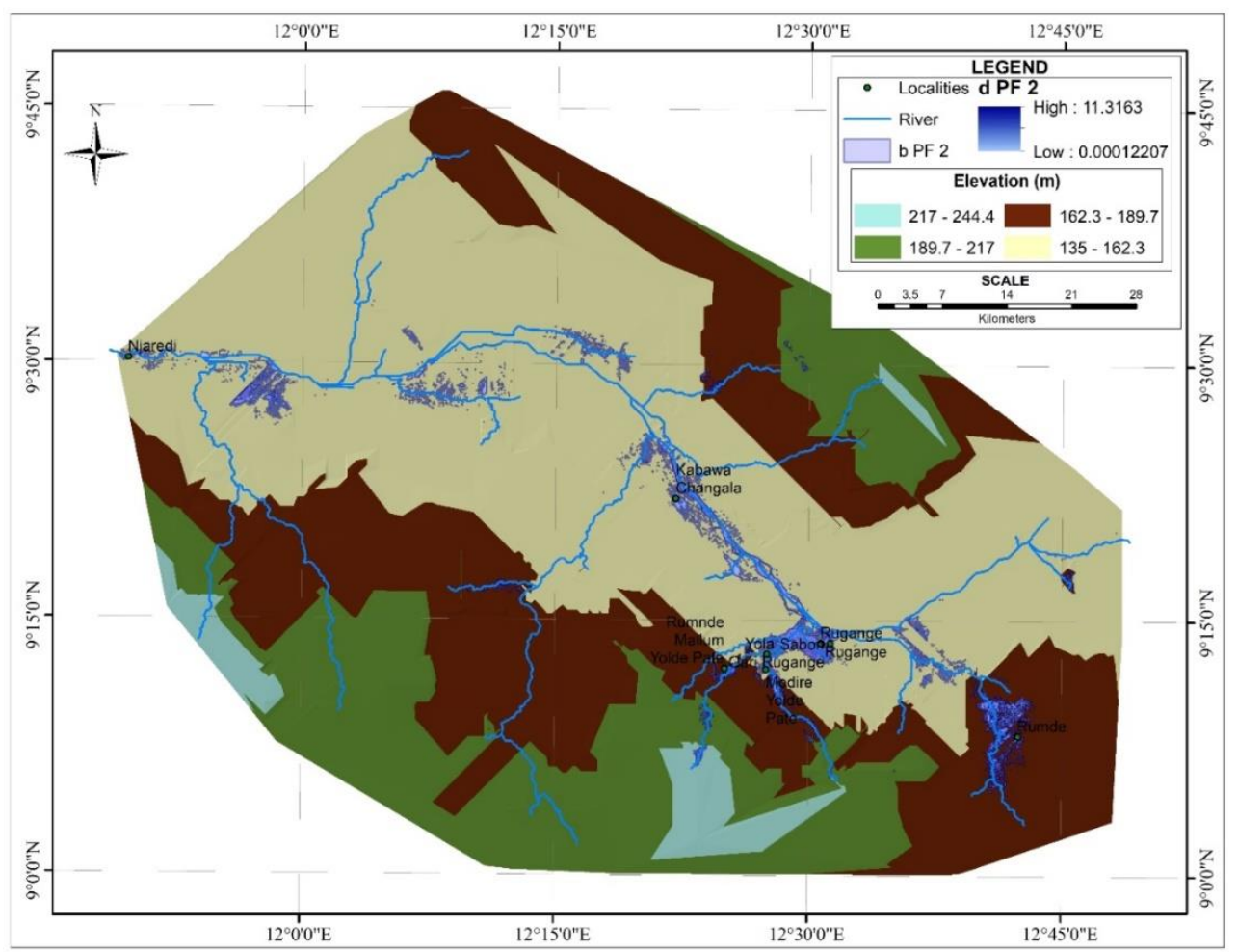

Figure 6: Floodplain for 2 years flow rate on study area

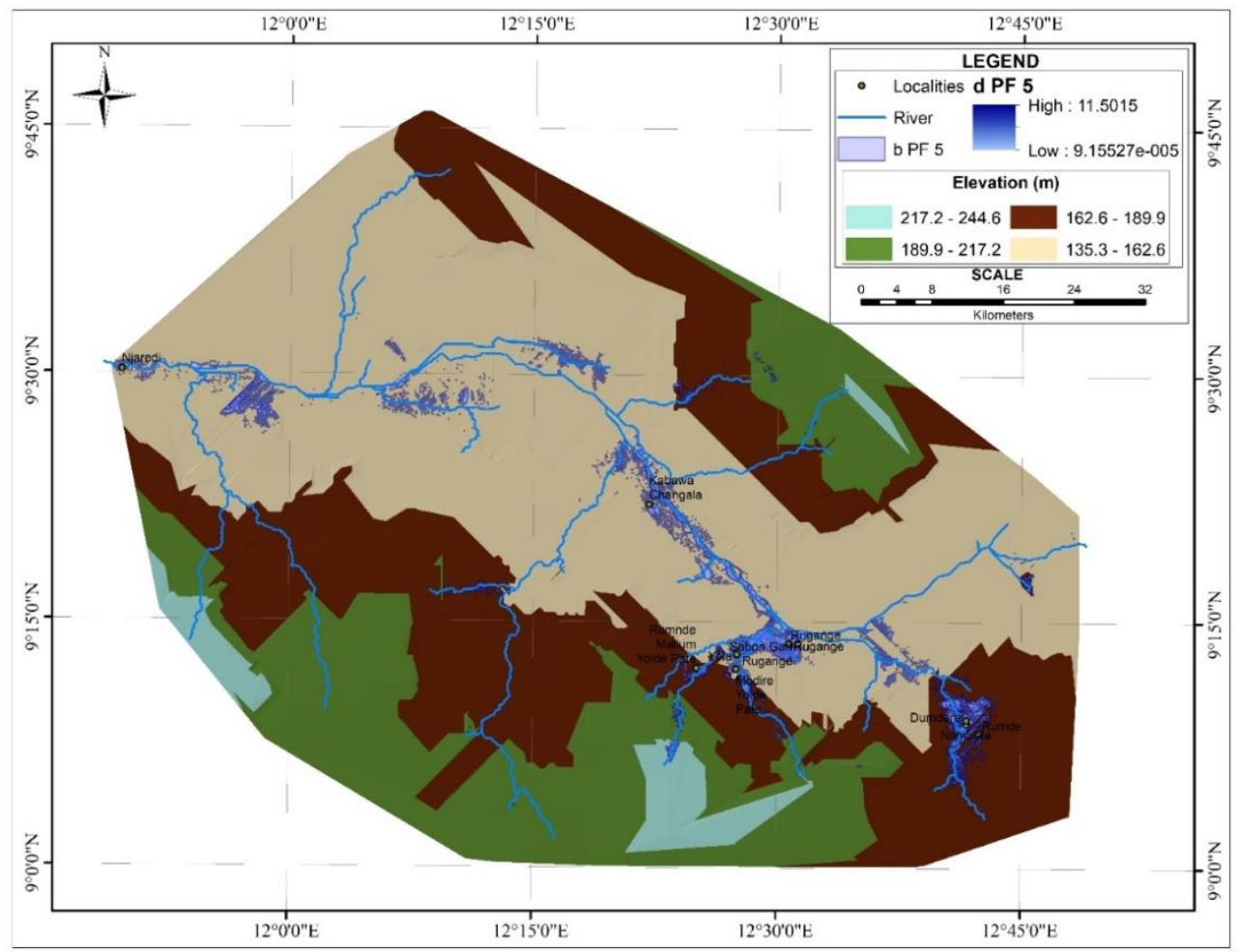

Figure 7: Floodplain for 5 years flow rate on study area

Analysis of 10 years flood (Figure 8) or AEP of $10 \%$ shows that the total number of areas highly prone to flood is eleven (11). The specific localities include: Nambare, Rumude, Dumdere, Njaredi, Kabawa Changala, Rugange, Sabon Gari Rugange, Yola, Shagari, Rumude Mallum Yolde Pate, and Modire Yolde Pate (Figure 8). The probability of a flood of this calibre (10\% or 0.1$)$ to occur and affect those localities in a given year is relatively low compared to both the $2 \mathrm{yr}$ and $5 \mathrm{yr}$ flood. The results show that as the recurrence interval (RI), being $2 \mathrm{yr}, 5 \mathrm{yr}$ and $10 \mathrm{yr}$ flood, keep increasing, their 
Annual Exceedance Probability or chances of occurrence keep decreasing. In worst case scenario, there could be $100 \mathrm{yr}$ flood (1\% AEP), $200 \mathrm{yr}$ flood (0.5\% AEP) and $500 \mathrm{yr}$ flood ( $0.2 \%$ AEP). This study has provided information on the extent of flooding and floodwater inundation.

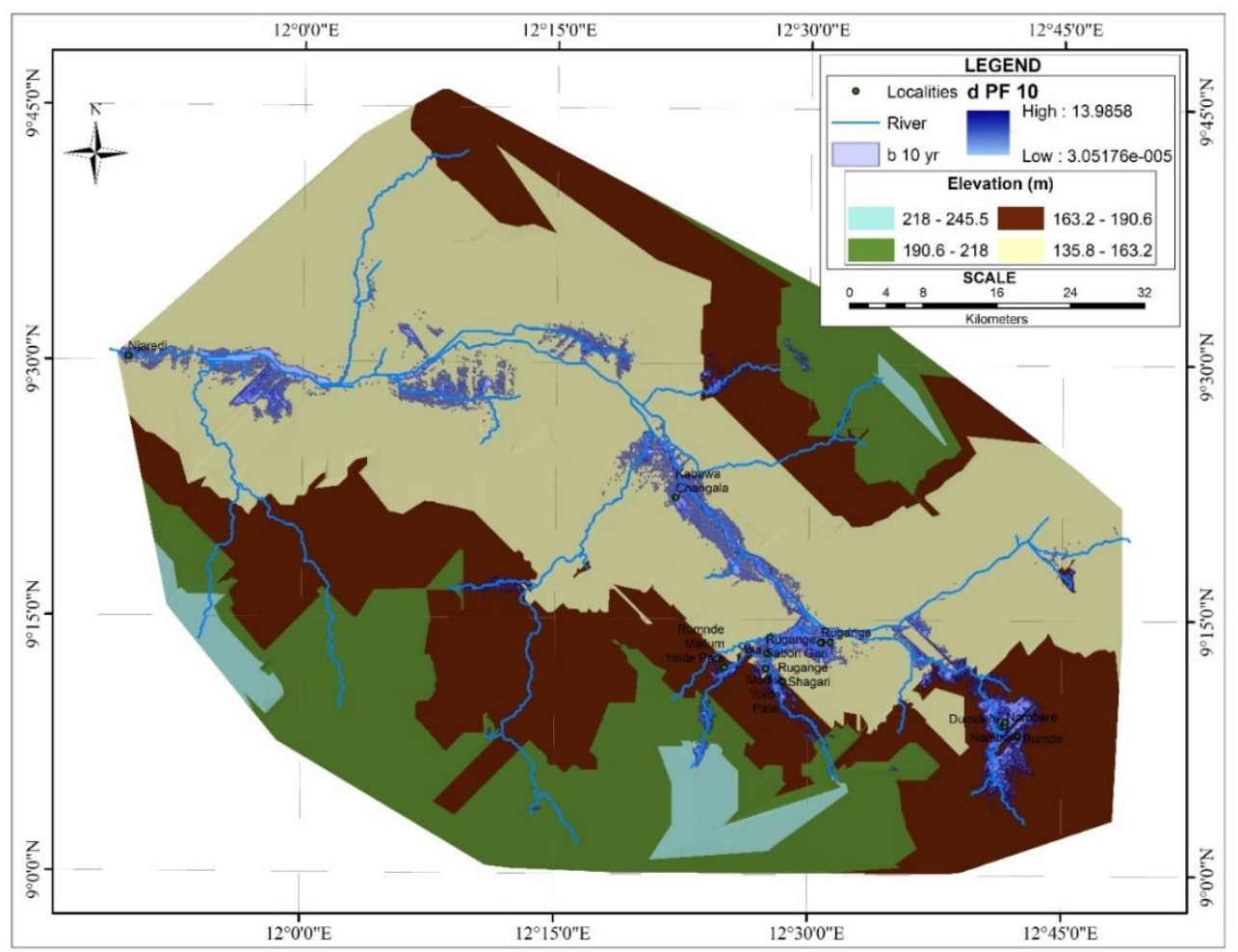

Figure 8: Floodplain for 10 years flow rate on study area

\subsection{Conclusions}

This present study has provided information regarding localities or areas prone to flood at various peak flows and how land use and soil permeability affects the severity of flood in Adamawa catchment, Nigeria. Geospatial techniques, HEC-GeoRAS and HEC-RAS model have thus been applied. The Benue River basin particularly Adamawa catchment is characterized by extensive fertile land which have led to intensification of agriculture in some areas and urban growth in other areas. These have exposed a large population to flood risk during the wet season, as the Benue River usually overflows its banks and sometimes, extreme floods also occur in the catchment. Three flow rates were specifically analyzed ( 2 years, 5 years and 10 years) based on availability of flow data, and the resulting floodplains were mapped. Results of 2 years flood show that eight localities in the study area are highly prone to flood. The number of localities prone to flood increases for Annual Exceedance Probability of $20 \%$ and $10 \%$. Modelling results generated a curve number grid map which shows the permeability levels within the study area. Findings reveal that larger parts of the catchment have more infiltration capacity which implies reduced surface runoff whereas areas more prone to water logging are about $12.9 \%$ of the total catchment.

\section{References}

Adebayo, A. A. (1997). The Agroclimatology of rice production in Adamawa State, Nigeria. Unpublished Ph.D. Thesis, Department of Geography, FUT, Minna, Nigeria.

Akintunde, J. A., Adzandeh, A. E. and Fabiyi, O. O. (2016). Spatio-temporal pattern of urban growth in Jos Metropolis, Nigeria. Remote Sensing Applications: Society and Environment, 4, pp. 44-54.

Burkham, D. E. (1972). Channel changes of the Gila River in Safford Valley, Arizona, 1846-1970: U.S. Geological Survey Professional Paper, 655-G, 24. 
Capon, T., Parsons, M. and Thoms, M. (2009). Floodplain ecosystems: resilience, value of ecosystem services and principles for diverting water from floodplains. Waterlines report, National Water Commission, Canberra. Commonwealth of Australia, ISBN 978-1-921107-87-0, 87p.

Christopherson, R. W. (2012). Geosystems: An Introduction to physical Geography. 8th ed. Pearson Education Inc. Prentice Hall. ISBN-13: 978-0-321-70622-5, pp. 398-410.

Coffman, D. K., Greg, M. and Franklin T. H. (2000). Characterization of Geomorphic Units in the Alluvial Valleys and Channels of Gulf Coastal Plain Rivers in Texas, with Examples from the Brazos, Sabine, and Trinity Rivers. USGS, Science for a Changing World. In cooperation with the Texas Water Development BoardScientific Investigations Report 2011-5067, pp. 1-32.

Duda, R. Hart, P. and Stork, D. (2000). Pattern Classification, Second edition. A Wiley- Interscience Publication, New York.

Food and Agriculture Organization of the United Nations (FAO) (1997). Africover Land Cover Classification. Environment and Natural Resources Service, Sustainable Development Dept., Rome.

Food and Agriculture Organization of the United Nations (FAO), (2005). Land Cover Classification System (LCCS), Classification Concepts and User's Manual. FAO, Rome, Italy.

FISRWG (1998). Stream Corridor Restoration-Principles, Processes and Practices: Federal Interagency Stream Restoration Working Group (FISRWG), GPO Item No. 0120-A; SupDocs No. 57.6/2: EN 3/PT.653, ISBN-0-934213-59-3.

Grosshans, R., Venema, H., and Barg, S., (2005). Geographical Analysis of Cumulative Threats to Prairie Water Re-sources: Mapping Water Availability, Water Quality, and Water Use Stresses. International Institute for Sustain-able Development, Winnipeg, Manitoba, p. 40 .

Lowery, B., Hickey, W. J., Arshad, M. A. and La, R. (1996). Soil Water Parameters and Soil Quality; Doran, J.W., Jones, A.J., Eds.; Methods for Assessing Soil Quality: Madison, WI, USA; pp. 143-55.

NFDP-II (2003). Environmental and Social Impact Assessment of the Second National FADAMA Development. Federal Ministry of Agriculture and Rural Development, Project Coordination Unit. E776, 1, pp. 2728-2829.

Nicholls, N. and Wong, K. K. (1990). Dependence of Rainfall Variability on Mean Rainfall, Latitude, and the Southern Oscillation. J. Clim. 3, pp. 163-170.

Nwilo, P. C. Olayinka, D. N. and Adzandeh, E. A. (2012). Flood Modelling and Vulnerability Assessment of Settlements in the Adamawa State Floodplain using GIS and Cellular Framework Approach. Global Journal of Human Social Science, 12(3), pp. 11-20.

OAS/DRDE (1991). Primer on Natural Hazard Management in Integrated Regional Development Planning. Chapter 8: Floodplain definition and Flood Hazard Assessment. Department of Regional Development and Environment Executive Secretariat for Economic and Social Affairs Organization of American States with support from the Office of Foreign Disaster Assistance United States Agency for International Development Washington, D.C. Accessed: 11/04/2014. Retrieved from: https://www.oas.org/dsd/publications/Unit/oea66e/begin.htm.

Paillex, A., Doledec, S., Castella, E. and Merigoux, S. (2009). Large river floodplain restoration: Prediction species richness and trait responses to the restoration of hydrological connectivity. Journal of Applied Ecology, pp. 1-9, doi: 10.1111/j.1365-2664.2008.01593.x. 
Schumm, S. A. and Lichty, R.W. (1963). Channel widening and flood-plain construction along the Cimmaron River in south-western Kansas: U.S. Geological Survey Professional Paper 352-D, pp. $71-88$.

Schmudde, T. H. (1968). "Floodplain". In: R.W. Fairbridge. The Encyclopedia of Geomorphology, New York: Reinhold, pp. 359-362.

Strahler, A. and Merali, Z. (2007). Visualizing Physical Geography. The Wiley BicentennialKnowledge for Generation, pp. 365-378.

Subhajit, G., Allen, J. L., Singer, M. B. and Rolf, A. (2010). Channel and Floodplain Change Analysis over a 100- Year Period: Yuba River California. Remote Sensing, 2, pp. 1797-1825. doi: $10.3390 /$ rs2071797.

Subhankar, K., Slobodan, P. S., Peck, A., and Black, J. (2010). An Information System for Risk-Vulnerability Assessment to Flood. Journal of Geographic Information System, 2, 129146. doi:10.4236/jgis.2010.23020.

SURCON (2004). Hydrographic Survey Standards in Nigeria. Surveyors Council of Nigeria Stakeholders Workshop on Hydrographic Surveying held at the Federal Palace Hotel, Lagos. $29^{\text {th }}$ January, 2004.

Tockner, K., and Standford, J. A., (2002) Riverine Floodplains: Present state and future trends. Environmental Conservation, 29, pp. 308-330.

US-ACE, (2011). HEC-GeoRAS- GIS tools for support of HEC-RAS using ArcGIS, user's manual, Institute for water resources, Hydrologic engineering centre report CPD-83, US Army Corps of Engineers, Davis, California, USA.

US-SCS (1986). U.S. Soil Conservation Service. Technical Release 55: Urban Hydrology for Small Watersheds, U.S. Department of Agriculture.

US Army Corps of Engineers (US ACE) (2011). HEC-GeoRAS- GIS tools for support of HEC-RAS using ArcGIS, user's manual, Institute for water resources, Hydrologic engineering center report CPD-83, Davis, California, USA.

Wolman, M. G. and Leopold, L. B. (1957). River floodplains: some observations on their formation. USGS Prof. Pap. 282-C, pp. 87- 109.

Xinyi, D., (2016). Dam site selection using an integrated method of AHP and GIS for decision making support in Bortala, Northwest China. Lund University Publications. In Lund University GEM thesis series NGEM01 20161. Accessed: 11/05/2019. Retrieved from: https://lup.lub.lu.se/studentpapers/search/publication/8886448

Cite this article as:

Nwilo P. C., Olayinka N. D. and Adzandeh A. E., 2019. Analysis of Impact of Exposures and Hydrological Modelling of Flood Peak Zones in Adamawa Catchment, Nigeria. Nigerian Journal of Environmental Sciences and Technology, 3(2), pp. 256-267. https://doi.org/10.36263/nijest.2019.02.0148 